Columbia Law School

Scholarship Archive

\title{
The Belated Decline of Literalism in Professional Responsibility Doctrine: Soft Deception and the Rule of Law
}

William H. Simon

Columbia Law School,wsimon@law.columbia.edu

Follow this and additional works at: https://scholarship.law.columbia.edu/faculty_scholarship

Part of the Legal Ethics and Professional Responsibility Commons, and the Rule of Law Commons

\section{Recommended Citation}

William H. Simon, The Belated Decline of Literalism in Professional Responsibility Doctrine: Soft Deception and the Rule of Law, 70 Fordham L. REV. 1881 (2002).

Available at: https://scholarship.law.columbia.edu/faculty_scholarship/874 


\title{
THE BELATED DECLINE OF LITERALISM IN PROFESSIONAL RESPONSIBILITY DOCTRINE: SOFT DECEPTION AND THE RULE OF LAW
}

\author{
William H. Simon*
}

Literalism is the doctrine that a facially accurate but knowingly deceptive statement does not violate prohibitions of falsehood and misrepresentation. This essay argues that Literalism has had greater legitimacy in professional responsibility than in other areas of law, but that it seems to be in terminal decline. It surveys the arguments for and against Literalism and concludes that its impending demise should be welcomed.

\section{LITERALISM V. CONTEXTUALISM}

- In the course of a divorce trial, the husband testifies that he acquired certain property as trustee for his mother:

Judge: [to Husband on the stand]: Where is your mother ... ?

Husband: In Salem. ${ }^{1}$

Husband's lawyer knows that the statement is true only in the sense that the mother is buried in Salem. If the judge or Wife's counsel understood that the mother had died, further questions would bring out that the Husband had inherited the property, which would be highly material to the Wife's claims for support and property division. Husband's counsel, however, takes no action with respect to his client's response. ${ }^{2}$

- Banking regulators ask a Savings and Loan Association to produce underwriting files for specified loans. With the knowledge of counsel, bank officers produce files which have been labeled with the names of the loans but to which some documents have been added and others removed since the time of the loan commitment. This is inconsistent

* Stephen and Barbara Friedman Visiting Professor of Law, Columbia University. For Deborah Rhode. Thanks for comments to Alan Hyde and participants in discussions at Fordham and Columbia.

1. In re A, 554 P.2d 479 (Or. 1976).

2. Id. 
with customary record-keeping practice. Counsel does not mention the alterations to the regulators. ${ }^{3}$

- A wrongful death action is brought against a drug company by the survivors of an asthmatic child. The child died after taking, in the course of a viral infection, a drug made by the defendant. The company denies that it had sufficient knowledge of danger from the drug to have had any duty to warn the child's physician. The trade name of the drug is Somophyllin Oral Liquid; its active ingredient is theophyllin. In discovery, plaintiff demands production of "[a]11 documents pertaining to any warning letters ... regarding the use of the drug Somophyllin Oral Liquid."4 Defendant's counsel responds that there were no such letters, even though they are aware of a letter referring to "life threatening toxicity when pediatric asthmatics [on theophyllin] contract viral infections." The letter, however, made no mention of the trade name Somophyllin Oral Liquid. ${ }^{5}$

Each of these cases led to professional responsibility charges, and in each, counsel relied on Literalistic interpretations of his duties. Under a Literalistic approach, an actor's response is adequate as long as it is not misleading under any of the meanings that can be nonfrivolously attributed to it. The range of eligible meanings includes those that are independent of the context of the response and thus rely mainly on the surface or dictionary meaning of the words. The first lawyer is thus free to rely on an interpretation of the judge's questions as concerned only with the mother's physical whereabouts; the second is free to treat the bank examiner's request as asking for the documents that happen to be in the files at the moment; and the third can respond as if the plaintiff was asking only for information pertaining to theophyllin drugs with a particular trade name.

Literalism is a response to "asymmetric ambiguity." The professional responsibility issues with which it is concerned most often involve someone asking for information (the "asker") and someone responding to a request or demand for it (the "responder"). The responder is making a statement that she is aware has more than one non-frivolous interpretation. The asker may have introduced the ambiguity through an imprecision in her request or question. It is likely that the asker is unaware of the ambiguity precisely because she has less information about the subject than the responder. Moreover,

3. In re Fishbein, OTS AP 92-19, II 74-93 (1992) (reporting allegations of Office of Thrift Supervision), reprinted in Practising Law Institute, The Attorney-Client Relationship After Kaye, Scholer 237, 257-62, 272-85 (1992). The allegations mentioned above represent one of seven charges of deceptive conduct, all disputed by the lawyers.

4. Wash. St. Physicians Ins. Exch. \& Ass'n v. Fisons Corp., 858 P.2d 1054, 1081 (Wash. 1993).

5. Id. at 1075 . 
in the situation with which we are concerned, the ambiguity arises from a divergence between a literal and a contextual meaning. The distinction is a matter of degree. All meanings are contextual, but a literal interpretation disregards all but a minimal range of context. A contextual interpretation takes in the entire range of factors that can be conveniently taken account of.

In situations of asysmmetric ambiguity, Literalism stands for two points. First, it puts the costs of ambiguity and the burden of clarification on the asker. Second, it accords as much respect to literal or surface interpretations as to substantive or contextual ones. The responder is as free to rely on the former as on the latter. ${ }^{6}$

An alternative to the Literalist response to asymmetric ambiguity might be called contextual, purposive, or substantive. An example of a substantive approach is the fraud standard of the Restatement (Second) of Torts, which includes this:

A representation that the maker knows to be capable of two interpretations, one of which he knows to be false and the other true is fraudulent if it is made:

(a) with the intention that it be understood in the sense in which it is false, or

(b) without any belief or expectation as to how it will be understood, or

(c) with reckless indifference as to how it will be understood. ${ }^{7}$

The touchstone here is the addressee's understanding, which makes context relevant. Note also that the speaker who is aware of ambiguity - the responder in our case-has a very high burden of clarification. Not only is he not free to rely on interpretations that he knows the addressee will not assume, but he cannot rely even on interpretations that it appears the addressee might not assume. If there is ambiguity, he must clarify it if he speaks.

Under a Contextual approach such as the Restatement's, the three scenarios are easy cases. Counsel in the divorce case knows that the judge is likely to understand "in Salem" to mean that the mother is living in Salem. Counsel in the bank examination is at least recklessly indifferent to the prospect that the examiners will interpret their response to mean that the documents in the files were there at the time of the loan decision and that the files contain all the documents

6. E.g., David E. Kendall et al., Preliminary Memorandum Concerning Referral of Office of Independent Counsel, H.R. Doc. No. 105-317, at 26 (1998) [hereinafter Kendall et al., Preliminary Memorandum] ("If answers are truthful or literally truthful but misleading, there is no perjury as a matter of law, no matter how misleading the testimony is or is intended to be. The law simply does not require the witness to aid his interrogator.").

7. Restatement (Second) of Torts $\$ 527$ (1977). 
on which the decisions were based. Defense counsel in the drug case knows that plaintiff's counsel intends its request to include drugs that are medically equivalent to the one in issue regardless of trade name and hence knows that its response will be understood to mean that there are no documents with respect to any such drugs. ${ }^{8}$

The remainder of this essay suggests that Literalism has remained far more influential in professional responsibility than it has in other fields, but that its influence seems to be declining. It then rehearses the arguments for and against Literalism and tries to substantiate the widely-shared intuition that it is pernicious.

\section{LITERALISM OUTSIDE AND INSIDE PROFESSIONAL RESPONSIBILITY}

\section{A. Outside}

Outside professional responsibility, a powerful tendency in American legal thought has been to move away from Literalism toward Contextualism. Hostility to Literalism is prominent in the work of all the most highly-regarded modern legal theorists from Cardozo to Dworkin. In private law doctrine, Contextualism had triumphed by the mid-twentieth century. I have already quoted the Contextual standard of the Restatement (Second) of Torts on fraud. ${ }^{9}$ Similarly, both the Restatement (Second) of Contracts and the Uniform Commercial Code mandate Contextual interpretation of contract terms. ${ }^{10}$

The Restatement (Second) of Contract's provisions on deception and mistake repudiate Literalism in precisely the kind of situation we are concerned with. "Half truths," as well as explicit falsehoods, can warrant recission. ${ }^{11}$ When one contracting party has "reason to know" that the second party attaches a different meaning to a term than she and the second is unaware of the divergence, the second party's meaning controls. ${ }^{12}$ Where one party "has reason to know" that the

8. Of course, in a Literalistic regime, the asker will try to make her questions unambiguous and will be attentive to Literalistic interpretations. To the extent that these efforts are successful, the main difference from the asker's point of view between a Literalistic and a Contextual regime is that she has to work harder under the latter. However, it seems likely that such efforts will have only limited success and that askers will inadvertently assume mistaken interpretations under Literalism.

9. See supra note 7 and accompanying text.

10. Restatement (Second) of Contracts $\$ \S 153(b), 159,201$ (1981); U.C.C. $\$ 1$ 201(3) (2001) ("agreement" found, as well as "in ... language," also "by implication from other circumstances including course of dealing or usage of trade or course of performance").

11. Restatement (Second) of Contracts $\S 159$, cmt. b, illus. 4 (seller of apartment house who represents that apartments rent for $\$ 200$ without also disclosing that these rents are illegal under the rent control law makes actionable misrepresentation).

12. Id. $\S 201(2)$. 
second's manifest agreement is premised on a material mistake of the second party, the contract is not binding on the second party. ${ }^{13}$ For example, if a prospective sub-contractor has submitted a bid that is based on an arithmetical miscalculation reasonably observable by the general contractor, the sub-contractor is not bound. ${ }^{14}$

In civil procedure, the Federal Rules reject Literalism at several points. For example: "Denials shall fairly meet the substance of the averments denied." "[A]n evasive or incomplete disclosure, answer, or response [in discovery] is to be treated as a failure to disclose, answer, or respond." 16

Literalism seems to have a stronger presence in criminal law. At most, however, it is a one-way role. Some authority allows the defendant to appeal to Literalism where a statute is clumsily drafted or the government pleads inadequately or the prosecutor asks an ambiguous question on cross-examination. On the other hand, the government's obligations to the defendant are defined and interpreted contextually. The government's Brady obligation to turn over exculpatory evidence, for example, does not require a specific, unambiguous demand by the defendant. The government must make its own judgment about materiality, on a contextual understanding, and then volunteer the information. ${ }^{17}$

Moreover, even pro-defendant Literalism has eroded in the criminal sphere. Cases in the perjury area, for example, are divided.

13. Id. $\S 153(\mathrm{~b})$.

14. Id. $\S 153(\mathrm{~b})$, cmt. e, illus. 9 .

15. Fed. R. Civ. P. 8(b).

16. Id. R. 37(a)(3).

17. On Brady duties, see Wayne R. Lafave et al., Criminal Procedure 1098-1107 (3d ed. 2000).

A notorious prosecutorial reliance on Literalism occurred in the examination of Captain Proctor, the ballistics expert in the trial of Sacco and Vanzetti:

Q: Have you an opinion as to whether bullet No. $3 \ldots$ was fired from the

Colt automatic, which is in evidence [Sacco's pistol]?

A: I have.

$\mathrm{Q}:$ And what is your opinion?

A: My opinion is that it is consistent with being fired from that pistol.

After the conviction, Proctor conceded to the defense that "[a]t no time was I able to find any evidence whatever which tended to convince me that the particular model bullet found in Berardelli's body... came from Sacco's pistol" and that the prosecutor had framed the question in order to avoid eliciting a negative answer. Neither the trial court nor the appeals court found any problem with the prosecutor's conduct. Felix Frankfurter, The Case of Sacco and Vanzetti: A Critical Analysis for Lawyers and Laymen 77-78, 81-82, 88-89 (1927).

I doubt, however, that anyone would defend the expert's testimony today. See, for example, Alcorta v. Texas, 355 U.S. 28, 31 (1957), in which the Court, per Justice Frankfurter, found a due process violation in the prosecutor's knowing elicitation of testimony which, "taken as a whole [conveyed a] false impression." (In Alcorta, the witness denied that he was "in love" with the victim or had had "dates" with her, which he and the prosecutor apparently believed to be literally true, while both knew that the witness had had sexual intercourse with her on several occasions. Id. at 30.) 
In the Bronston case, much invoked by President Clinton's lawyers in the Lewinsky affair, the Supreme Court reversed a perjury conviction based on the following exchange:

Q: Do you have any bank accounts in Swiss banks, Mr. Bronston?

A: No, sir.

Q: Have you ever?

A: The company had an account there for about six months, in Zurich. $^{18}$

The answer was misleading; the examiner interpreted it to mean that the witness had not had a personal account, and in fact he had. But the Court held it noncriminal; insofar as it referred explicitly only to the corporation, it was literally true.

However, in other cases involving misleadingly ambiguous answers, convictions have been upheld. For example, the Fifth Circuit upheld a conviction based on a series of exchanges such as this:

Q: Didn't you meet with a lady at a hotel here in New Orleans on several occasions when you came down?

A: No. I did not. ${ }^{19}$

The answer was true under the "literal" interpretation of "New Orleans" as within the legal boundaries of the city, since the meeting took place in the adjacent suburb of Kenner, but the answer was false under the interpretation of "New Orleans" meaning the New Orleans metropolitan area, which context indicated was the one intended by the examiner. ${ }^{20}$

Aside from perjury, criminal offenses for deception rarely require literal falsity. Criminal fraud doctrine, like civil fraud, has evolved away from Literalism. ${ }^{21}$ And, as Stuart Green concludes, with the

18. Bronston v. United States, 409 U.S. 352, 354 (1973).

19. United States v. Fulbright, 804 F.2d 847,850 (5th Cir. 1986).

20. Id. at 851; see also United States v. DeZarn, 157 F.3d 1042, 1049 (6th Cir. 1998) (in perjury case falsity is measured in terms of the "context of the questioning"). These cases distinguish Bronston by the fact that there the answer was unresponsive on its face. The referee asked about individual bank accounts, and the witness responded in terms of corporate bank accounts. Had the referee been attentive, she would have followed up by insisting on a specific answer about individual accounts. (Of course, one could say in Fulbright and DeZarn that, had the prosecutor been attentive, she would have made her initial question less ambiguous.)

One litigation situation where Contextualism has long been uncontroversial is the common practice of asking questions on cross-examination in the form: "Isn't it true that $x$ ?" The answer "yes" is invariably interpreted to mean that $x$ is true, notwithstanding that the literal meaning is the opposite. Lawyers would never think of trying to get some advantage by appealing to this literal meaning. Contextual interpretation is so entrenched here that lawyers are no longer aware of the literal interpretation.

21. Wayne R. LaFave, Criminal Law 829-33 (3d ed. 2000). 
newer, more specialized statutory offenses, such as mail or securities fraud, "literal falsity is seldom, if ever, required."22

The popular attitude toward Literalism seems to have remained the one depicted by Shakespeare in The Merchant of Venice. Literalism, as exemplified by Shylock's insistence on holding Antonio to his promise of a pound of flesh, is presumptively deplored. It is defensible and admirable only when used as a last resort to thwart some substantive injustice, as with Portia's counter-move based on a Literalistic interpretation of "flesh" to mean only skin and not blood."

Thus, the Literalistic defenses of President Clinton against the perjury charges appear to have been met largely with contempt. Clinton's lawyers argued that the answer that Clinton had not had sex with Monica Lewinsky was true under the lengthy written definition of "sex" the Jones lawyers had filed. Clinton also argued that his ordinary-language understanding of "sex" did not include oral sex. These arguments did not seem to persuade many. ${ }^{24}$ People tended to scoff or (if they were sympathetic on other grounds) wink at them. Clinton's congressional defenders did not rely on these points.

Even within a Literalistic perspective, Clinton's arguments were debatable. A careful reading of the plaintiff's definition does not support Clinton's interpretation, but the verbiage is dense, and it is

22. Stuart P. Green, Lying, Misleading, and Falsey Denying: How Moral Concepts Inform the Law of Perjury, Fraud, and False Statements, 53 Hastings LJ. 157, 188 (2001).

23. Shylock proposes the bond "in a merry sport," William Shakespeare, The Merchant of Venice, act I, sc. 3, then when Antonio defaults, insists on literal enforcement. Portia responds that "the words expressly" give him rights only to flesh, not blood. Id. act IV, sc. 1.

24. See Jones v. Clinton, 36 F. Supp. 2d 1118, 1130 (E.D. Ark. 1999) (dismissing Clinton's arguments based on "tortured definitions and interpretations of the term 'sexual relations'"); Robert Novak, Triumph of the Hair-Splitters, N.Y. Post, Jan. 25, 1999, at 27 (reporting popular disdain for President's "legalistic" arguments); Patrick: Oster, Kill the Lawyers?, Nat'I L.J., Dec. 21, 1998, at A20 (same).

There were two main arguments about discovery answers. First, Clinton denied that he had had "sexual relations" with any federal employee in response to an interrogatory that did not define the term. His defense was that "sexual relations" requires "intercourse" and does not include oral sex. Kendall et al, Preliminary Memorandum, supra note 6 , at 7 .

Second, during the deposition he was asked the same question after being given a definition that stipulated that "a person engages in 'sexual relations" when the person knowingly engages in or causes... contact with the genitalia, anus, groin, breasts, inner thigh, or buttocks of any person with an intent to arouse or gratify the sexual desire of any person." Referral from Independent Counsel Kenneth W. Starr in Conformity with the Requirements of Title 28, United States Code, Section 595(c), H.R. Doc. No. 105-310, at 133 (1998) [hereinafter Starr Report]. In effect, Clinton's defenders argued that the definition applies only where a person causes contact with a specified body part of another person and only for the purpose of arousing or gratifying the sexual desire of the other person. As Judge Wright characterized Clinton's position: "It appears the President is asserting that Ms. Lewinsky could be having sex with him while, at the same time, he was not having sex vith her." Jones, 36 F. Supp. $2 d$ at 1130 n.16. 
quite plausible that someone relying only on this language could have been confused. Judge Wright expressed concern at the time of the deposition that the definition was hard to follow and that the President might not understand it. $^{25}$ Ordinary-language usage of "sex" seems to vary with respect to whether it includes oral sex; Lewinsky used the word at least once on the Tripp tapes in a way that excluded oral sex. ${ }^{26}$

If the questions are viewed in the broader context of the Jones litigation, however, there can be no question that the Jones lawyers meant their questions to cover fellatio. The Jones lawyers were looking for conduct that resembled what Jones alleged occurred with her in the Arkansas hotel room. The conduct Jones alleged looks more than anything like a request for fellatio. So if the standard is Contextual, Clinton's defense is preposterous. Its general dismissal in popular discussion tends to confirm that popular morality applies a Contextual standard.

\section{B. In Professional Responsibility}

Literalism has never been rejected in professional responsibility as decisively as in general doctrine and popular morality. True, it has often been criticized by individual lawyers. Judge Marvin Frankel's 1975 article The Search for Truth is a widely noted example. ${ }^{27}$ But lawyers as a group have not come close to renunciation of it. Literalism has remained a respected, though contested, mainstream position.

The vitality of Literalism is most readily observed in the criminal sphere. Here, respectable opinion defends even some forms of active deception, and no doubt such views would accept the more passive form involved in Literalism. In the civil sphere, there is little discussion or authority squarely addressing the choice between Literalism and Contextualism. Nevertheless, the cases with which we began suggest that the influence of Literalism, though waning, is far from exhausted. Lawyers were sanctioned in all three cases. ${ }^{28}$ But two of them-Kaye Scholer, ${ }^{29}$ the bank case; and Fisons,${ }^{30}$ the drug

25. Deposition of William Jefferson Clinton, Jan. 17, 1998, Jones v. Clinton, C.A. No. LR-C-94-290 (E.D. Ark.), available at http://www.cnn.com/ALLPOLITICS/1998/ 03/13/jones.v.clinton.docs/clinton/oo.jpg.

26. Supplemental Materials to Referral from Independent Counsel Kenneth W. Starr in Conformity with the Requirements of Title 28, United States Code, Section 595(c), H.R. Doc. No. 105-316, at 2664 (1998).

27. Marvin E. Frankel, The Search for Truth: An Umpireal View, 123 U. Pa. L. Rev. 1031 (1975).

28. In the banking case, the lawyers agreed to pay a fine to settle the case prior to adjudication of the merits.

29. See supra note 3 and accompanying text.

30. See supra note 4 and accompanying text. 
case-were highly controversial within the bar and, to some extent, continue to be.

The Kaye Scholer lawyers responded to the Office of Thrift Supervision ("OTS") charges of deception, including the one concerning document production described above, by appealing to Literalism. With the support of Geoffrey Hazard, the reporter for the ABA Model Rules, they argued that the standard for judging their behavior was Model Rule of Professional Responsibility 3.1 on "Meritorious Claims and Contentions," which requires only that a statement have a "basis... that is not frivolous." 31 As applied to argument or the assertion of legal conclusions on the basis of matters of record in an adjudicatory proceeding, the non-frivolous standard is uncontroversial. The danger of misleading ambiguity in this area is small, since the basis for the statements is in view of everyone. But Hazard's assertion that the non-frivolous standard of Rule 3.1 applied to factual statements in informal dealings amounted to a radical assertion of Literalism in situations where the potential for misleading ambiguity is pervasive. He suggested that it did not matter whether the Kaye Scholer lawyers knew their responses were misleadingly incomplete or intended that they be so, so long as there was some interpretation under which the statements were non-frivolous.

A chorus of bar leaders and institutions offered vigorous support for Kaye Scholer after the OTS charges. It is difficult, however, to distinguish the extent to which the support was premised on acceptance of the firm's Literalist position on the misrepresentation charges. Much of the support was focused on an unusually aggressive remedy OTS employed at the outset of the case-a "freeze" of the firm's assets under the banking laws. And when Kaye Scholer's supporters discussed the merits they often portrayed the charges inaccurately (for example, as complaining of nondisclosure rather than misleading disclosure) and, therefore, responded confusingly. Nevertheless, none of the supporters made any effort to distance themselves from Kaye Scholer's Literalist arguments. ${ }^{32}$ Particularly notable in this respect was Judge Frankel, perhaps the most famous critic of Literalism, who endorsed Kaye Scholer's position without qualification in an op-ed piece. ${ }^{33}$

31. Geoffrey C. Hazard, Stummary of Opinion of Geoffrey C. Hazard, Jr., reprinted in Practising Law Institute, supra note 3, at 381. Hazard ignored what would seem to be the more directly pertinent prohibitions against making "a false statement of material fact" of Model Rules 3.3 and 4.1. No doubt he found it hard to argue that "misrepresentation" should be given a Literalist reading here when tort authority so strongly supports a Contextualist one.

32. The response to the Kaye Scholer charges is described in William H. Simon, The Kaye Scholer Affair: The Lawyer's Duty of Candor and the Bar's Temptations of Evasion and Apology, 23 Law \& Soc. Inquiry 243, 259-82 (1998).

33. Marvin E. Frankel, Lawyers Can't Be Stool Pigeons, N.Y. Times, Mar. 14, 1992, at A25. Judge Frankel seems to have misunderstood the charges, see Simon, 
Fisons was less discussed than Kaye Scholer, but the proceedings did produce some indication of lawyer support for Literalism. Unlike Kaye Scholer, in which OTS's misconduct claim was based substantially on professional responsibility norms, the plaintiff's charges in Fisons alleged only a violation of the discovery provisions of the civil procedure rules. However, the defense lawyers invoked professional responsibility norms in their response. They argued that the civil procedure rules should not be interpreted to impose requirements inconsistent with professional responsibility norms and that professional responsibility norms either forbade or did not require turning over even clearly material and important documents in response to an ambiguous request. They were able to support this claim with opinions from no less than fourteen ethics experts, including two former presidents of the Washington State bar and (again) Geoffrey Hazard. In denying sanctions, the trial judge found withholding the document "was consistent with the customary and accepted litigation practices of the bar of Snohomish County and of this state." 34 In overruling, the Washington Supreme Court did not dispute this finding; it just treated it as irrelevant. In effect, it indicated that it wanted the customary practices to change.

Literalism thus appears to retain substantial support within the bar. On the other hand, our three cases, and some others, ${ }^{35}$ raise the question whether the position is eroding. Cases like In re $A$ ("Where is your mother?") that preclude Literalist deception in responses to a judge seem not to have provoked protest. ${ }^{36}$ Although Fisons provoked a strong Literalist defense in the lower court, the state supreme court's repudiation of Literalism in the discovery context, though widely noted, has met with little open criticism. OTS's challenge in the banking context was technically a stand-off; it was never decided on the merits. But the massive defense of Kaye Scholer focused mainly on issues other than the ones involving Literalism, and some professional responsibility textbooks now report the charges with some sympathy.

supra note 32 , at 261-62, and it's not clear he intended to endorse the Literalist aspects of Kaye Scholer's defense.

34. Wash. J. Physicians Ins. Exch. \& Ass'n v. Fisons Corp., 858 P.2d 1054, 1078 (Wash. 1993) (Washington Supreme Court opinion reporting trial court disposition); Stuart Taylor, Jr., Sleazy in Seattle, Am. Law., Apr. 1994, at 5 (describing Fison's expert supporters).

35. E.g., United States v. Benjamin, 328 F.2d 854, 862 (2d Cir. 1964) (upholding criminal convictions of lawyer and accountant under the securities laws for various implicit misrepresentations, such as "[ $[\mathrm{t}]$ he statements that certain assets had not been 'verified by direct communication' implied that with this qualification all assets had been verified by suitable means [even though] they had not been").

36. See also Spaulding v. Zimmerman, 116 N.W.2d 704 (1962) (approving vacation of judicial approval of settlement on behalf of minor where opposing counsel failed to volunteer material information to court). 


\section{Behind or Ahead of the Times?}

It remains to be seen whether this picture of professional responsibility as a jurisprudential laggard should be revised as a consequence of the renewed defense of "formalism" and "textualism" in public and commercial law. Textualism has acquired new prestige in recent years, and Formalism has been defended explicitly for the first time in many decades.

Whether professional responsibility Literalists can take heart from this development is not clear. In many respects, the arguments advanced in favor of Formalism and Textualism seem irrelevant to our issues.

Many of the new Textualists or Formalists disclaim Literalism and insist on their openness to a significant range of Contextual interpretations. $^{37}$ Moreover, many of them value text or form as evidence of either the intention of the law-maker or the probable understanding of the addressee. By contrast, our Literalists are indifferent to both the responder's intention and the asker's understanding. Finally, Textualists and Formalists often believe that there is a single best interpretation of the statement in question, and their prescriptions are designed to identify it. Literalists, on the other hand, insist that within a broad range one understanding is as good as another. (Indeed, the term Literalism is somewhat misleading, since Literalists are happy to permit the responder to rely on Contextual interpretation when it is to his advantage to do so.) While Textualists and Formalists tend to have a strict or essentialist attitude toward interpretation, the Literalist attitude is anarchic.

Moreover, the circumstances to which the new arguments have been applied seem different from ours. Much of the Formalist and Textualist argument has been focused on public law situations where the state confronts private citizens directly, while Literalism is most often concerned with private law situations where private citizens are disputing with each other. Defenses of Formalism in the commercial sphere are typically focused on situations of repeat dealings among members of a common trade, where problems of asymmetric information are not frequent. ${ }^{38}$

Nevertheless, there is some kinship between the new FormalistTextualist arguments and the Literalist position in professional responsibility. Textualists and Formalists often proceed from a libertarian orientation; they value their methods as ways to constrain

37. See Antonin Scalia, A Matter of Interpretation 24 (1997) ("good textualist" is not a Literalist); John F. Manning, Textualism as a Nondelegation Doctrine, 97 Colum. L. Rev. 673, 696 (1997) ("Textualism is not literalism.").

38. See, e.g., Robert Scott, The Case for Formalism in Relational Contract, 94 Nw. U. L. Rev. 847, 874 (2000) ("Nothing in the case for formalism would preclude judicial policing of firms seeking to use literal language as a vehicle to exploit consumers or other 'occasional' contractors."). 
state power. Although these concerns are less salient in the private sphere, the Contextualist position does require more judicial intervention to protect the victims of asymmetric ambiguity than the Literalist one. A strong distrust of state actors would thus weigh against Contextualism. There is, in addition, an affinity between the argument made by John Manning that Textualism functions to induce the legislature to clarify its statutes ${ }^{39}$ and the Literalist position that seeks to encourage the asker to reduce the ambiguity of her requests.

On balance, the new Textualism and Formalism might be seen as a reversal of the trend away from Literalism, but a small one that provides only slight support for the professional responsibility Literalism.

\section{THE CASE AgAINST LITERALISM}

It seems worth trying to set out the best arguments for and against Literalism. The conclusion that Literalism should be rejected will not be surprising. But neither the arguments for nor the ones against Literalism have been clearly articulated. So even if a review of them produces no novel conclusion, it may add some confidence to the disposition to reject it.

I focus on situations where the responder knows what information the asker is seeking, and has no principled objection to providing it aside from the ambiguity of the question or request. Thus, I am less interested in situations where we may be sympathetic to the responder because the asker threatens some substantive right-for example, where the asker seeks to invade the responder's privacy, or to deprive her of an economic return on information she has invested resources in developing, or to force her to incriminate herself. There are important arguments in such situations in favor of deception, explicit or implicit. ${ }^{40}$ Although I occasionally refer to such situations, especially Clinton's testimony about sex with Lewinsky, I intend to bracket questions of the defensibility of deception tout court and consider simply whether a literally true but knowingly deceptive response should be deemed legitimate where a literally false one would not be.

\section{A. Core Objections}

There are three principal arguments against Literalism-focused on, respectively, deception, the rule of law, and the adversary system. Moralism, 12 Geo. J. Legal Ethics 433 (1999). 


\section{Deception}

Literalism is a form of deception. From the responder's point of view, Literalistic deception is distinguishable because the responder is more passive than the actor in core cases of deception. Nevertheless, she is not entirely passive; she does speak in a knowingly misleading way. And from the asker's point of view, the effect is the same as in the core case. The asker is misled. Thus, the basic moral objections to deception seem applicable here: It is a failure of both respect and solidarity.

\section{The Rule of Law}

Literalism is in tension with rule-of-law values. The rule of law prescribes that disputes be resolved and social conduct governed in accordance with duly promulgated legal norms. Such resolution and governance requires that enforcers have material information available to them. Literalism threatens this pre-requisite by permitting the withholding of material information.

The problem arises from dispersal of information. Some people have material information not available to others that it is not in their interests to disclose. Literalism puts a high burden on the party seeking the information to specify her demand. However, precisely because she does not have the information, she is in an inferior position to do so. A Contextual rule puts the burden of resolving ambiguity on the person who is in the best position to do so-the one who has the information. Thus, a Contextual norm produces more material information, and this serves the rule of law.

The rule-of-law value bears on transactional as well as litigation practice. The rule of law is designed to protect autonomy, and the fullest exercise of autonomy within legally prescribed boundaries requires that transacting parties have the information that is material to them.

A related point can be made in efficiency terms. Access to material information generally makes for better adjudicative and transactional decisions. Assigning the duty to clarify ambiguity to the party with the most information is a lower-cost way of making material information available to enforcers and transactors.

\section{The Adversary System}

The third argument asserts that the Contextual understanding is most compatible with the desirable features of the adversary system as we practice it.

Some use the adversary system as a trump that favors any position that puts client loyalty above nonclient interests. But if we look for connotations that are both well-established in our system and 
distinguish it from other systems (notably those of the civil law countries), we find that the adversary system stands primarily for the principle of party autonomy. Under this principle, basic responsibility for defining issues and presenting evidence belongs to the parties and their counsel, rather than to public officials. One virtue claimed for this approach is that it increases the chance that the adjudicator will give fair consideration to all relevant points of view. The presence of competing advocates asserting their perspectives throughout the proceeding prevents the adjudicator from allowing preconceptions developed early on from dulling her sensitivity to inconsistent evidence. Another virtue is that parties are more likely to regard as legitimate a decision that follows consideration of the arguments and evidence they have chosen to present. ${ }^{41}$

So viewed, the virtues of the adversary system depend on shared party control over the presentation of evidence to the trier. They do not depend at all on a party's unilateral control over the other's access to evidence. Quite the contrary. Meaningful control over presentation requires that each counsel have full access to the evidence that she might find relevant. Neither full consideration of points of view nor legitimacy can be achieved unless each party has had and believes that she has had full access. This suggests both that discovery rights should be broad and that such rights should be interpreted in the perspective of the asker. The responder is not in a position to make an objective judgment about materiality, but even if she were, such a judgment is beside the point. The key thing is that each party have an opportunity to present the evidence that she regards as probative. No doubt safeguards against unreasonable and bad faith demands are needed. But Literalism goes much farther. It justifies the responder in disregarding the asker's intentions whenever there is ambiguity in her request. This is contrary to the spirit of party autonomy, and thus, the adversary system.

\section{B. Responses and Rebuttals}

Here is how Literalism responds to the three criticisms and why the responses are unconvincing:

\section{Deception}

Literalists often assert that the asker is "responsible" for his own deception where the statement is literally true..$^{42}$ Sometimes they add

41. See Mirjan Damaska, The Faces of Justice and State Authority 160-64 (1986) (emphasizing legitimacy benefits); Lon Fuller, The Adversary System, in Talks on American Law 30 (Harold Berman ed., 1961) (emphasizing cognitive benefits of party autonomy).

42. See, e.g., Green, supra note 22, at 5-8; cf. Immanuel Kant, Lectures on Ethics 226 (Peter Heath trans., 1997) ("[I]f I pack my bags, for example, people will think I 
that the asker could have asked a clearer question or followed-up. This distinguishes the express deception case only by degree, since there are always some measures that the asker can take to verify any statement. The measures may be less costly on average with implicit deception, but the question remains why the asker should be expected to undertake any more effort than necessary to communicate her intention.

Perhaps the Literalists believe that the asker should suffer for disrespecting some social convention about reasonable inferences. If someone relied on a plainly unreasonable interpretation of a statement I made, convention might accept my failure to correct it. (For example, she inferred from my saying I was from Texas that I was wealthy and lent me money in reliance.) But there does not seem to be any categorical social convention against reliance on Contextual interpretation. On the contrary, the norms exemplified by the Restatements clearly assume that mistaken interpretation of literally true statements is often reasonable.

A better argument is that implicit deception is less blameworthy than explicit deception because the deceiver is less active and because the victim's sense of betrayal will be weaker. The claim rests on the omission/commission distinction that, though sometimes hard to justify in principle, has strong support in intuition and convention. But conceding the premise that explicit deception is worse does not necessarily lead to the conclusion that implicit deception is acceptable. The Contextualist can still contend that implicit deception is bad enough to warrant prohibition, and we've seen that, at least in the civil sphere, there is ample support in substantive law for this notion.

If we ask why implicit deception seems less bad, the answer is likely to be that it is closer to the situation where the subject is entirely silent. Here the subject is simply a bystander who knows that another suffers from a misunderstanding. Yet, even in this situation, many would argue that there ought to be a "duty to rescue" if the subject can spare the other major loss without incurring substantial cost herself.

The "duty to rescue" is strongest where aid is costless to the subject. In our situation, there is a cost-the information damages the responder's position in the litigation or negotiation. If the responder can point to some defect in the process that will be exacerbated by disclosure, this might be a morally relevant cost. But if we concede that disclosure generally enhances the likelihood of a fair resolution (for reasons adduced in the rule-of-law and adversary system arguments), then the cost seems morally irrelevant. Increased

am off on a journey, and that is what I want them to believe; but they have no right to demand any declaration of will from me."). 
vulnerability to a disadvantageous but fair decision should not count against disclosure.

Whatever we conclude about the duty to rescue in the bystander situation, that situation seems remote from ours. The responder has usually placed himself in a relation with the asker in which he is actively seeking some advantage. He is himself seeking information from the asker, as well as making demands on or proposals to him. In the transactional context, he is bargaining for a relation with or benefit from the asker. In litigation, the plaintiff has initiated the proceeding by making allegations. The defendant may be an involuntary participant in some respects (although the case may arise out of his past voluntary conduct), but once the case is initiated, he does not remain a bystander; he takes positions on the merits and makes allegations of his own.

\section{Rule of Law}

There are two Literalist responses worth considering here. One asserts that Contextualism will undermine accurate determinations by deterring adequate preparation. Another asserts that it unfairly subjects the responder to uncertainty regarding his duties in particular situations.

The argument about preparation asserts that the stronger the duties to turn over adverse information, the less effort lawyers will spend preparing their own clients' cases. They will become lazy about preparation and will overestimate the degree of help they can expect from their adversaries and miss important evidence. Overall, preparation will be suboptimal, and adjudication will be less reliable.

This is unconvincing. To begin with, only a lawyer could conflate less lawyering with less efficiency. Less lawyering can mean more efficiency. Surely, it means more efficiency to the extent that less lawyering takes the form of less duplication of effort, more allocation of discovery burdens to parties with easiest access to evidence, and less effort spent anticipating and responding to opportunism and recalcitrance on the part of opposing parties.

The Clinton deposition is a good example. The Jones lawyers assumed that they might be operating under a Literalism standard or that Clinton's lawyers would assume that. So they spent a lot of time drafting an elaborate definition of "sexual relations." According to Clinton, however, they didn't spend enough time; they failed to anticipate and eliminate all the ambiguities.

Indeed, Clinton's response raises the question whether it is sometimes impossible to satisfy a Literalist standard. ${ }^{43}$ Many who

43. After reviewing the Fisons defendants' literalistic evasions, the Washington Supreme Court concluded, "[i]t appears clear that no conceivable discovery request could have been made... that would have uncovered the relevant document[]." 
have parsed the Jones lawyers' definition say that it really did preclude the ambiguity about whether fellatio was "sex" that Clinton appealed to. ${ }^{4}$ But Clinton also suggested that he simply didn't understand the definition. And of course, the more elaborate and complicated the question gets, the more plausibly the witness can claim not to understand it.

On the other hand, if they could have anticipated that Clinton's duty to answer would be defined contextually, the Jones lawyers could have saved themselves all the effort that went into framing the question and simply asked about "sexual relations" without elaboration. In context, no one would have doubted that they intended to cover oral sex (the focus of Jones's own allegations). The elimination of this kind of defensive lawyering under a Contextual regime would be a clear efficiency gain.

Of course, a reduction in lawyering is a clear efficiency gain only if there is no reduction in the amount and quality of information generated. In fact, we might expect an increase in information under a Contextual standard from the lessened ability to take advantage of ambiguity to withhold adverse material. Clinton's prevarication might never have been discovered but for Linda Tripp's enterprising tape recording, and the Fisons "smoking gun" came forth only by the grace of a whistleblower. Neither contingency seems especially common. People will be tempted to withhold adverse information if they think they can get away with it regardless of the rules. However, if there is either voluntary compliance or a credible sanction threat (and surely there is), one might expect a Contextual standard to produce more information because it makes it easier to demand it.

Nevertheless, lawyers who dislike strong disclosure duties argue that there will be a reduction in the amount and quality produced because lawyers, once they become accustomed to relying on their adversaries to make their cases, will become lazy and naïve and fail to make adequate efforts on their own. The argument does not make much sense, however. If disclosure duties under a Contextual standard are perfectly enforced, then it will be both rational and socially desirable for lawyers to reduce their efforts. To the extent that they are not enforced, lawyers will be aware of that fact and will make more effort than in a world of perfect enforcement, though still probably less than in a Literalist world. Under any set of disclosure rules, lawyers will have to make judgments about the optimal level of effort to spend on preparation. There is no reason to think that these judgments will be less sound under less burdensome discovery procedures.

Wash. St. Physicians Ins. Exch. \& Ass'n v. Fisons Corp., 858 P.2d 1054, 1083 (Wash. 1993).

44. See Starr Report, supra note 24, at 1, 131-50. I find the Independent Counsel convincing on this point. 
The other Literalist response to rule-of-law concerns claims that Contextualism subjects the responder to too much uncertainty about his responsibilities, and hence, liability. The Supreme Court rested its Literalist interpretation of the perjury statute on this consideration in Bronston:

To [reject Literalism] would be to inject a new and confusing element into the adversary testimonial system we know. Witnesses would be unsure of the extent of their responsibility for the misunderstandings and inadequacies of examiners .... 45

Even in the context of a criminal perjury prosecution the point is debatable. There may be more uncertainty in general about what compliance requires under a Contextual than under a Literalist standard, but requirements under a Contextual standard would often be clear enough. Some cases are ambiguous only in the sense that it is not clear that the responder is obliged to interpret the request contextually. Once we know that a Contextual standard applies, cases like the three with which we began are easy. Under any standard, a criminal conviction for perjury would require proof beyond a reasonable doubt that the defendant had knowingly misled the court. Where this requirement is not satisfied, the court should reverse for insufficient evidence. Where it is satisfied, an additional requirement of Literalism does not seem to add anything of value.

More importantly, whatever plausbility the argument has in the perjury context depends on the asymmetry of stakes peculiar to criminal prosecution. We deem erroneous conviction far more costly than erroneous acquittal. But there is no comparable asymmetry in the civil sphere. There it is a fatal objection that whatever certainty Literalism adds for the responder must come at the expense of greater uncertainty for the asker. The diminished risk of mistaken sanction for the responder requires an increased risk of loss of material information, and hence mistaken determination on the merits, for the asker.

\section{The Adversary System}

Literalism may derive some support from ideas about the adversary system such as those expressed by Justice Scalia in his critique of the 1993 Federal Rules of Civil Procedure amendments requiring production without demand of adverse information:

The proposed new regime does not fit comfortably within the American judicial system, which relies on adversarial litigation to develop the facts before a neutral decisionmaker. By placing upon lawyers the obligation to disclose information damaging to their clients-on their own initiative, and in a context where the lines

45. Bronston v. United States, 409 U.S 352, at 359 (1973). 
between what must be disclosed and what need not be disclosed are not clear but require the exercise of considerable judgment - the new Rule would place intolerable strain upon lawyers' ethical duty to represent their clients and not to assist the opposing side. ${ }^{46}$

We must overlook the hyperbole here. If a duty is inconsistent with the adversary system simply because it benefits the opposing side, then we have never had an adversary system. Even before modern discovery, lawyers had duties, such as the prohibition on lying and presenting false evidence, designed to benefit opposing parties. Of course, the modern discovery rules, which govern what has come to be the principal litigation activity in our system, consists entirely of duties intended to benefit opposing parties.

However, Justice Scalia's remarks seem to suggest, in addition to the certainty point we dismissed above, two further specific arguments:

(1) Judgments under a Contextual standard are especially difficult because they require the lawyer to take the opposing party's point of view. I suggested above that the adversary system encourages this in discovery by prescribing that each party have access to the evidence he believes is relevant. ${ }^{47}$ But clearly it also contemplates that the lawyer take his own client's point of view in preparing and presenting the case at trial. Thus, it requires the lawyer to shift back and forth between opposing points of view. Scalia suggests that lawyers would have difficulty doing this and that the adversary system implies that client loyalty prevails.

This argument, however, misunderstands lawyering as it is practiced even under an ethic of strong client loyalty. As Anthony Kronman recently emphasized, the traditional self-image of the profession has emphasized, not just identification with, but also detachment from clients. ${ }^{48}$ Not client loyalty alone, but this simultaneous sympathy and detachment constitutes the distinctive trait of effective lawyering. The lawyer seeks to benefit the client by inducing trust and reliance in others. The lawyer could not perform this role if she were not able to understand the perspective of public officials and adverse parties. The "cardinal rule" in John W. Davis's famous article on advocacy is, not, Identify with the Client!, but, "Change places (in your imagination of course) with the Court."49 Roger Fisher and William Ury insist, "the

46. 53 CCH S. Ct. Bull. B2094, B2098 (Apr. 22, 1993) (emphasis added).

47. See supra section III.A.3.

48. Anthony T. Kronman, The Lost Lawyer (1993).

49. John W. Davis, The Argument of an Appeal, 26 A.B.A. J. 895, 896 (1940); see also Robert E. Keeton, Trial Tactics and Methods 6 (2d ed. 1973) ("To be an effective trial lawyer you must maintain perspective.... In each instance, let your decision on whether to make a certain point ... be guided ... by your appraisal of the effect that your making the point may have upon the jury's and judge's consideration of all other aspects of the case."). 
ability to see the situation as the other side sees it ... is one of the most important skills a negotiator can possess."

(2) It is demoralizing to force lawyers to take actions that benefit interests adverse to their clients, and it is especially demoralizing to require them to exercise their professional skills in some challenging way for the benefit of nonclients.

Stress and demoralization are costs worth taking account of, but we do not usually regard them as sufficient objections to a social practice that produces substantial benefits. No doubt police officers find it stressful to give Miranda warnings or to cease interrogations when a suspect asks for a lawyer, but no one would think this a sufficient reason to eliminate these duties.

Moreover, the benefits of disclosure compliance may have a compensating tendency to enhance morale. The more confident we are that the case has been determined on the basis of all relevant information, the more reason we have to think that justice has been done. The lawyer who wins after disclosing adverse information should take that much more satisfaction in his work. The lawyer who loses should have the consolation that the result was more likely a just one. The lawyer who wins knowing that material adverse information has been withheld should feel stress from the knowledge that he may have participated in an injustice.

No doubt lawyers experience more stress from having to disclose information damaging to their clients than they do from having to conceal such information even when it is material. And perhaps this asymmetry is inevitable. But there is nothing desirable about such feelings and no reason to encourage them.

\section{Lawyering is Not a Game}

The last refuge of arguments for overly-aggressive lawyering is the claim that lawyering is a game and that deception and concealment are part of the rules. Deceptive lawyering is, like bluffing in poker, permissible because everyone expects and accepts it. It is fair because the opportunities to deceive and conceal are available to everyone. And both historically and semantically, the adversary system has always connoted a role for strategic cleverness, even at the cost of obfuscation.

It is undeniable that game rhetoric and attitudes have always appealed to some lawyers. It is easy to see why. The game perspective puts the lawyers' technical skills at the center of the picture and makes them an end in themselves. It is natural for lawyers to take satisfaction in the products of their own cleverness. This view,

50. Roger Fisher \& William Ury, Getting to Yes: Negotiating Agreement Without Giving In 23-24 (1981). 
however, has had little appeal to laypeople. Moreover, it is indefensible as an ethical basis for practical decision-making.

The game perspective is hard to criticize because it is rarely articulated reflectively, but we can note two important features of games that make them an inappropriate analogy to the legal process.

First, people usually play games voluntarily and for fun. By contrast, people have to enter the legal process to pursue and preserve basic social and economic goods. The fact that the rules are known and equally applied may be a sufficient guarantee of fairness where the costs of not playing are trivial, but where the stakes and pressures to play are high, more is required.

Second, the only measure of fairness in a game is procedural. But the legal process exists in substantial measure to vindicate the substantive law, and substantive legal norms provide an independent measure of the fairness of its results. A lawyering practice that impedes decision on the substantive merits cannot be just simply because everyone knows about it or has an opportunity to engage in it.

\section{CONCLUSION}

If the arguments for Literalism are so bad, how do we account for the bar's stubborn attachment to it? No doubt a sincere but mistaken belief in the arguments rejected here is part of the explanation. No doubt the natural psychological disposition of client loyalty also figures strongly. But we should note that there is a further, less flattering explanation. Literalism has at least a modest correlation with the economic self-interest of the bar. It is consistent with the bar's perceived material interest in minimizing the lawyer's responsibilities to people who do not pay for the lawyer's services. Moreover, it seems to have some tendency to enlarge demand for legal services. Under a Literalist regime, more lawyering is needed to produce any given amount of information. While this is the opposite of efficiency from a social point of view, it makes good economic sense for lawyers. 